\title{
Investigation of the pollution status and the waste reusing ability in trade village Duong Lieu, Hoai Duc, Hanoi
}

\author{
Khảo sát tình trạng ô nhiễm và tiềm năng tái sử dụng chất thải ở làng nghè \\ Dương Liê̂u, Hoài Đức, Hà Nội
}

Short communication

Nguyen, Phuong Hanh*; Chu, Thi Thu Ha

Institute of Ecology and Biological Resources, Vietnam Academy of Science and Technology, 18 Hoang Quoc Viet, Hanoi, Vietnam

\begin{abstract}
Vietnam has about 2,000 trade villages locating mainly in the north. Duong Lieu village in Hoai Duc, Hanoi, is one of the key areas of agricultural production and food processing. However, this area is affected by serious environmental pollution, particularly caused by solid waste and wastewater. Solid wastes of the starch production process from arrowroot are disposed in large amounts and represent the main reason for environmental pollution in Duong Lieu village. These wastes are present anywhere in this village, for example on the main road, in gardens, event fill in ponds and ditches. The components of the dried arrowroot waste are mainly carbon-rich substances such as starch (5\%), cellulose $(90 \%)$ and N, P, K $(0.5 \% ; 0.11 \% ; 0.16 \%$, respectively). The fresh arrowroot waste has humidity of up to $80 \%$. This substrate is suitable for culture of straw mushroom and oyster mushroom. The mushrooms use cellulose as carbon source for their growth. Therefore, waste from arrowroot that can be recycled efficiently by the biological method for culturing mushrooms. This treatment method is suitable to the conditions of Vietnam because it does not only reduce waste residues but also is environmentally friendly.
\end{abstract}

Việt nam có khoảng 2000 làng nghề và tập trung chủ yếu ở miền Bắc. Duoong Liễu là một trong những vùng trọng điểm chế biến nông sản thực phẩm. Song hiện tại khu vưc này đang bi ô nhiếm môi truờng nghiêm trọng, đặc biệt ô nhiếm rác thải và nuớc thải. Chất thải rắn của quá trình chế biến tinh bột tù̀ củ dong là rất lớn. Nó có mặt khắp noi tù trong nhà ra ngoài ngõ thậm chí lấp đầy cống rãnh, ao hồ. Đây chính là nguyên nhân gây nên ô nhiếm môi trương vùng làng nghề. Thành phần của bã dong rất giàu cellulose (90\%), tinh bột (5\%) và có cả nito; photpho, kali tuong vói 0,5\%, 0,11\% và 0,16\%; độ ẩm của bã dong tuơi lên tới $80 \%$. Co chất này thích hợp để trồng nấm rơm và nấm sò. Bởi các loại nấm này sủ dụng cellulose là nguồn cung cấp cacbon chính để sinh truởng. Do vậy, bã thải tù̀ củ dong có thể được tái sư dụng hiệu quả bằng phuong pháp sinh học nhu là dùng trồng nấm. Đây là một sụ lựa chọn phù hợp với điều kiện Việt Nam, vùa giảm thiểu chất thải dư thù̀a vì̀a thân thiện với môi trương.

Keywords: $\quad$ solid wastes, mushroom, arrowroot, biological method

\section{Introduction}

Vietnam is a developing country and has about 2,000 trade villages mainly concentrated in Northern regions (Dang Kim Chi, 2005; www.langnghe.org.vn). The activities of these trade villages lead to a noticeable degradation of environmental quality. Duong Lieu, located about $20 \mathrm{~km}$ west of Hanoi city centre, is a village famous in Hanoi for its agricultural products processing.
The advantage of trade village development is the economic benefit but the activities of this kind cause serious environmental pollution.

Processing of agricultural products is a traditional occupation here mainly practiced at household scale. There are about $65-75 \%$ of households in the commune engaging in this kind of work (Committee of Hoai Duc district, 2007). In this area, the two main concerned issues of pollution are related to food hygiene and to the 
management of waste, both being still not thoroughly solved. Figures 1, 2, 3 and 4 show the solid waste piled up on the main road, gardens and filled pond, drains.

In the past, with the small production scale, waste residues were usually transported to landfill. Nowadays, with expanded scale of production, the large amount of waste residue is about 400-500 tons/day (Committee of Hoai Duc district, 2007). The landfill method is no longer appropriate because of the land limitation and the soil and groundwater pollution by leachate from the landfill.

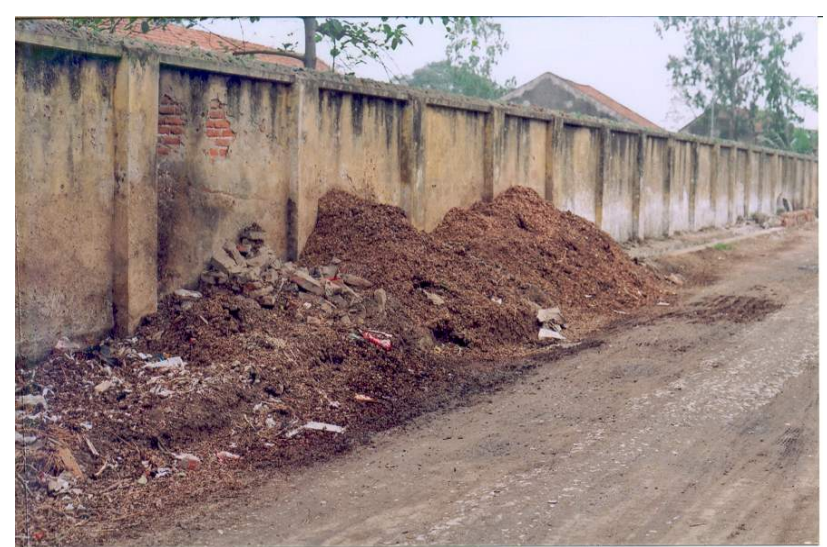

Figure 1. Waste disposal on the main road

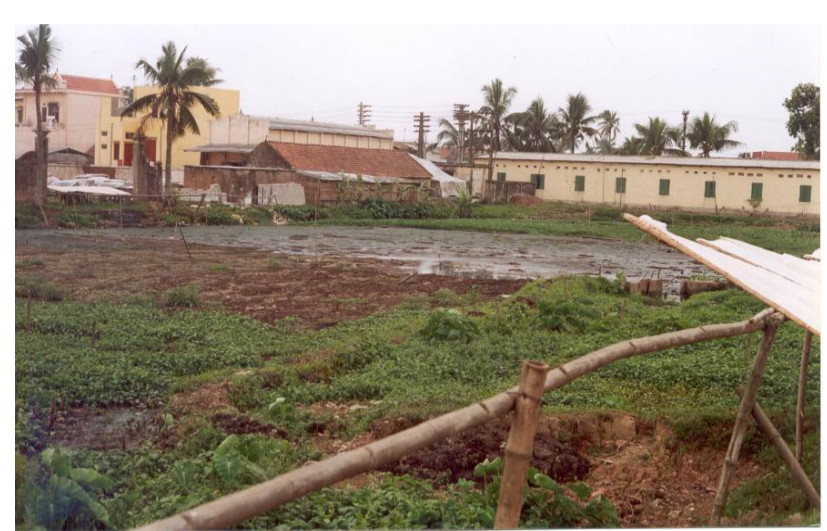

Figure 2. Pond filled with waste

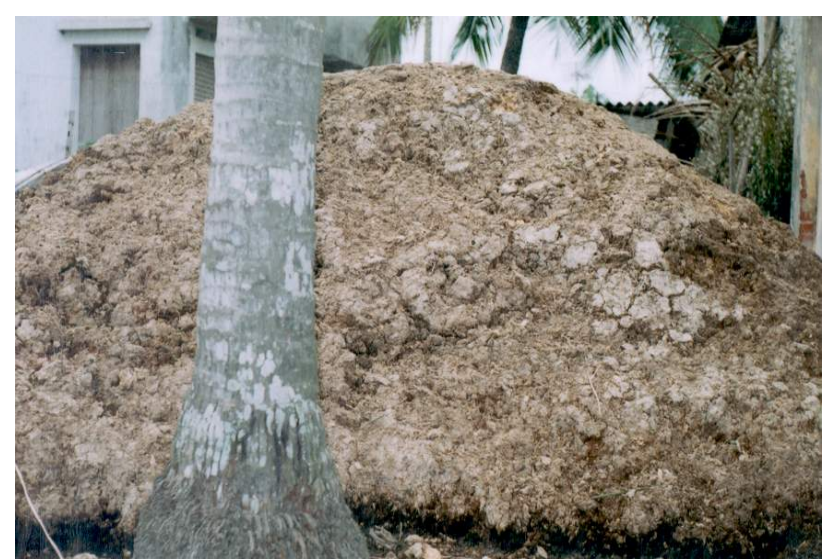

Figure 3. Waste deposited in garden

Many countries worldwide use waste materials as renewable resources (Dang Kim Chi, 2005; Vietnam Environment Administration, 2008). Waste of certain process can be the input source of other sectors in order to reduce environmental pollution.

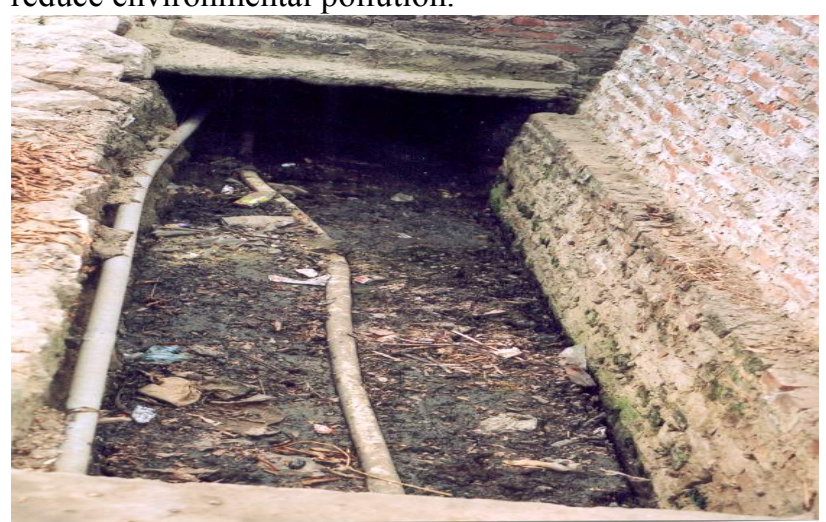

Figure 4. Filled drains

In Duong Lieu village today there are more and more solid wastes, but only very small amount of those are recycled. So, the threatening of environmental pressure to public health is very serious. The methods considered for the treatment of solid waste are biogas tanks or processing to make animal feed and fertilizer, however, they did not perform well. An alterative approach is growing mushrooms on waste residues from agricultural processing. This is regarded as an environmental friendly solution with potential economical benefit.

\section{Objectives and methods}

\subsection{Objectives}

- Solid wastes from the starch production process from arrowroot.

- Straw mushroom (Volvariella volvacea), oyster mushrooms (Pleurotus) and Cinnamon worm (Perionyx excavates)

\subsection{Methods}

- Field Survey.

- Quick interview method

- Determination of total $\mathrm{N}$ by Kieldahl method, $\mathrm{P}$ by colorimetric method, $\mathrm{K}$ by flame photometer and atomic absorption, $\mathrm{NO}_{3}$ by disulphophenic acid method

- Mushroom yield is calculated by ratio between weights of fresh mushrooms and of dry substrate.

\section{Results}

\subsection{Assessing the status of solid waste management from starch processing}

The Duong Lieu traditional village produces throughout the whole year, but the production concentrates mainly from October of previous year to April of next year (about six months). The materials used in processing cycle are cassava and arrowroot, amounting for tens of tons. The consequence is that a large amount of solid waste is disposed untreated into the environment (Table 1). 
Table 1. Input materials and solid wastes (output) of starch production in Duong Lieu village

\begin{tabular}{|c|c|c|c|c|c|c|c|c|}
\hline \multirow[t]{3}{*}{ Material } & \multicolumn{4}{|c|}{ Input material (tons) } & \multicolumn{4}{|c|}{ Solid waste (output), (tons) } \\
\hline & \multicolumn{4}{|c|}{ Time (year) } & \multicolumn{4}{|c|}{ Time (year) } \\
\hline & 2000 & 2001 & 2008 & 2010 & 2000 & 2001 & 2008 & 2010 \\
\hline Cassava & 116,000 & 125,000 & 150,000 & 171,000 & 47,000 & 48,000 & 51,000 & 57,000 \\
\hline Arrowroot & 31,000 & 52,000 & 66,000 & 82,000 & 10,000 & 16,000 & 22,000 & 25,600 \\
\hline Total & 146,000 & 172,000 & 216,000 & 253,000 & 56,000 & 64,000 & 73,000 & 82,600 \\
\hline
\end{tabular}

Table 1 indicates that starch processing in Duong Lieu villages disposed of thousands of tons of wastes per year, and the amount increased about 5\% - 10\% after each year. In the production process, approximately $13 \mathrm{~m}^{3}$ per 1 ton of arrowroot is discharged into surrounding environment. The wastewater is characterized by a high organic content, expressed through BOD and COD concentrations much higher than the standards (Table 2).

Table 2. Water quality in some places in starch production village Duong Lieu

\begin{tabular}{|c|c|c|c|c|c|c|c|c|}
\hline \multirow{2}{*}{ Samples } & \multicolumn{8}{|c|}{ Parameters } \\
\hline & $\mathrm{pH}$ & $\begin{array}{r}\text { Temperature } \\
\left({ }^{0} \mathrm{C}\right)\end{array}$ & $\begin{array}{r}\mathrm{SS} \\
(\mathrm{mg} / \mathrm{l})\end{array}$ & $\begin{array}{l}\mathrm{BOD}_{5} \\
(\mathrm{mg} / \mathrm{l})\end{array}$ & $\begin{array}{r}\mathrm{COD} \\
(\mathrm{mg} / \mathrm{l})\end{array}$ & $\begin{array}{l}\text { Coliform total } \\
(\mathrm{MPN} / 100 \mathrm{ml})\end{array}$ & $\begin{array}{r}\mathrm{N} \text { total } \\
(\mathrm{mg} / \mathrm{l})\end{array}$ & $\begin{array}{l}\text { P total } \\
(\mathrm{mg} / \mathrm{l})\end{array}$ \\
\hline N1 & 6.26 & 27.5 & 474 & 5506 & 6,406 & $900 \times 10^{3}$ & 154.02 & 29.93 \\
\hline N2 & 5.47 & 32.4 & 394 & 5656 & 8,666 & $22 \times 10^{3}$ & 85.12 & 16.19 \\
\hline N3 & 6.59 & 27.7 & 55 & 3473 & 5,010 & $8 \times 10^{3}$ & 39.76 & 8.48 \\
\hline N4 & 5.1 & 26.1 & 17 & 63 & 232 & $13 \times 10^{3}$ & 5.6 & 0.05 \\
\hline $\begin{array}{l}\text { Vietnam standard 5945: } 2005 \\
\text { (column B) }\end{array}$ & $5.5-9$ & 40 & 100 & 50 & 80 & 5,000 & 30 & 6 \\
\hline
\end{tabular}

where:

Samples Place N1 Wastewater of production of arrowroot N2 Wastewater of production of arrowroot starch in the household in Doan Ket hamlet

\subsection{The use of waste residue from starch processing}

People reuse the waste generated from starch processing for different purposes. The survey showed that the wastes from cassava tubers were reused $90 \%$ as feed for cattle, poultry or as fertilizer. In this rural area, wastes from arrowroot were sometimes dried and used as fuel.

\section{Samples Place \\ N3 Wastewater of production of cassava starch in the household in Dong Phu hamlet \\ N4 Irrigation ditch between fields}

Table 3. Status use of the waste residues of starch production process in Duong Lieu village

\begin{tabular}{ccccc} 
Solid waste & \multicolumn{3}{c}{ Solid Waste is use (\%) } & Solid waste not be reused (\%) \\
\cline { 2 - 4 } & animal feed & fuel & fertilizer & \\
Cassava waste & 30 & 0 & 60 & 10 \\
Arrowroot waste & 0 & 5 & 0 & 95
\end{tabular}

Table 3 indicates that cassava waste is mostly reused, whereas arrowroot waste is not reused but wasted. The local challenge is to manage and treat this waste in order for economic benefit and to reduce its impact on the surrounding environment.

\subsection{Prospects for reuse and treatment of arrowroot residues from starch processing}

\subsubsection{Reuse capabilities of arrowroot wastes}

The utilisation flow can be: Arrowroot solid wastes $\rightarrow$ Cultivation of mushrooms $\rightarrow$ mushroom harvest and
However, today several fuel types are available such as gas, electricity, coal, and the fertilizer applied for agriculture is mainly micro-organic-based fertilizer. Hence, the direct reuse of waste residue as fuel and fertilizer is no longer of interest, so about $95 \%$ of wastes are disposed in environment without any treatment (Table 3).

residues (which after culture of mushrooms are used as fertilizer). The sources of arrowroot waste used in the above process should be carefully treated.

\subsubsection{Chemical composition of arrowroot waste}

Components of the dried arrowroot waste are mainly carbon-rich substances such as starch (5\%), cellulose (90\%) and N, P, K (0.5\%; 0.11\%; 0.16\%, respectively). The fresh arrowroot waste has humidity up to $80 \%$. This kind of waste is suitable for culture of straw mushrooms and oyster mushroom. These mushroom species use cellulose as carbon source for their growth. Therefore, 
waste from arrowroot can be recycled efficiently by this biological method.

\subsubsection{Treatment of the arrowroot waste to produce the} substrate for culturing mushrooms

Analyses have shown that starch and cellulose are the main components of this waste whereas $\mathrm{N}, \mathrm{P}$ and $\mathrm{K}$ are found in small amount, making the waste a suitable source of nutrients for many organisms such as fungi and other microorganisms. It is therefore assumed that the arrowroot waste can be treated by biological methods.

The production of oyster mushroom and straw mushroom cultivated on arrowroot waste are very low in comparison with the ones cultivated on rice straw and sawdust (Table 4). The solution for improvement of the mushroom yield can be to add some essential nutrients into the arrowroot waste before being used as the growth medium.

Table 4. Yield of mushrooms growing on the tradition substrate and on the arrowroot waste

Yield (\%)

\begin{tabular}{lcc}
\cline { 2 - 3 } Mushroom & On the arrowroot waste & On the straw and sawdust (tradition substrate) \\
\hline Straw mushroom & 5 & 10 \\
Oyster mushroom & 20 & 60
\end{tabular}

The yield (\%) is calculate as ratio between mushroom fresh weight and dry weight of arrowroot waste.

Substrates for culturing mushroom must be treated strictly and have enough nutrients. The required conditions for the growing of mushroom should ensure: $\mathrm{pH}$ values of 7 $8,65-70 \%$ humidity, N 2.0-2.5\%, P 1.2-1.5\%. Compared with these requirements, the arrowroot waste is not suitable and should be amended with nutrients before being used as the growing medium for the mushroom. For this, the starch shall be eliminated and dried to reduce the moisture, then soaked with diluted lime solution (1-2\%) to adjust $\mathrm{pH}$ to $7-8$. Adding $1-3 \%$ bran and an amount of $\mathrm{N}, \mathrm{P}$ and $\mathrm{K}$ will help to increase the content in nutrients.

Waste residues from arrowroot can be thus packed into bags and wet sterilized at a temperature range of 120-150 ${ }^{0} \mathrm{C}$ for 3-4 hours. After cooling down at room temperature, they can used as substrates to cultivate the mushrooms. For straw mushroom, piles of substrates weighing about $20 \mathrm{~kg} /$ pile are made, and for oyster mushroom, substrates are packed into plastic bags weighing 1.5-2.0 kg/bag.
The process of cultivation of straw mushroom and oyster mushroom on waste residue from the arrowroot starch processing is described as follows:

Dry arrowroot wastes $\rightarrow$ material pre-treatment $\rightarrow$ heap or bags $\rightarrow$ wet sterilization $\rightarrow$ seed implantation $\rightarrow$ care, watering $\rightarrow$ harvest $\rightarrow$ process.

Each species of mushroom was grown from two to five crops. On arrowroot wastes, oyster mushroom can be grown two crops, such as autumn-spring and summer. Growing productivity reached $60-100 \%$ in autumn-spring with harvest time lasts about a month. But in the summer it produced much lower yield (only 10-25\%) with short harvest time (10-15 days). In contrast with oyster mushroom, yield of straw mushroom is high in summer, and very low in autumn - spring season $(5 \%-12 \%)$.

The results of cultivating mushroom are shown in the following Table 5, Figure 5 and Figure 6.

Table 5. Time duration, pH, temperature optimum, harvesting and productivity of two species of mushrooms growing on the waste from arrowroot

\begin{tabular}{|c|c|c|c|c|c|}
\hline Mushroom species & $\begin{array}{l}\text { Time of culture } \\
\text { (month in year) }\end{array}$ & $\begin{array}{l}\text { Time of harvest } \\
\text { (days) }\end{array}$ & $\begin{array}{l}\text { Yield } \\
(\%)\end{array}$ & $\begin{array}{l}\text { Optimum } \\
\text { temperature }\left({ }^{0} \mathrm{C}\right)\end{array}$ & $\begin{array}{l}\text { Optimum } \\
\text { pH }\end{array}$ \\
\hline $\begin{array}{l}\text { Straw mushroom } \\
\text { (Volvariella volvaceae) }\end{array}$ & Jun., Jul., Aug. & $15-25$ & $25-30$ & $24-30$ & 8 \\
\hline Oyster mushroom & Feb., Mar. and & $25-30$ & $60-100$ & $15-20$ & $7-8$ \\
\hline
\end{tabular}

(Pleurotus) Sep., Oct., Nov

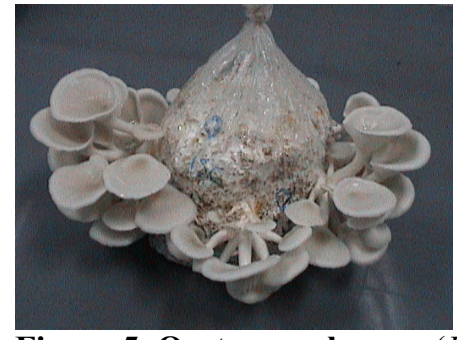

Figure 5. Oyster mushroom (Pleurotus)

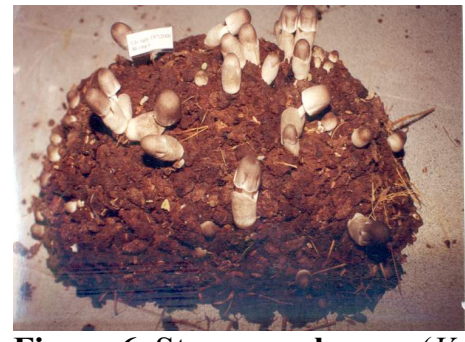

Figure 6. Straw mushroom (Volvariella volvaceae)

Besides factors such as temperature and $\mathrm{pH}$, the intensity of light and the seed quality of mushrooms also have great influences on harvested yields. 


\subsection{Producing vermicompost fertilizer from arrowroot waste residues by using blueworm (Perionyx excavatus)}

Arrowroot wastes after cultivation of mushroom were treated to produce vermicompost fertilizer. By using a blueworm species (Perionyx excavates) the organic materials in the arrowroot waste residues were decomposed into humus without odour to fertilize the agriculture soil.

The experimental formulas were conducted as follows:
Formula 1: Solid wastes of arrowroot being not used for cultivating mushroom and not decomposed by blueworms (control 1); solid wastes of arrowroot being used for cultivating mushroom and decomposed by blueworms (experiment 1).

Formula 2: Solid wastes of arrowroot being used for cultivating mushroom and not decomposed by blueworms (control 2); solid wastes of arrowroot being used for cultivating mushroom and decomposed by blueworms. Two experiments were performed after 2 months of raising blueworms. The experiment results are shown in Table 6.

Table 6. Composition of arrowroot solid wastes after raising blueworms

\begin{tabular}{llccccc} 
Experimental formula & $\begin{array}{c}\text { N total } \\
\mathbf{( \% )}\end{array}$ & $\begin{array}{c}\text { N available } \\
(\mathbf{m g} / \mathbf{1 0 0 g})\end{array}$ & $\begin{array}{c}\text { P total } \\
\mathbf{( \% )}\end{array}$ & $\begin{array}{c}\text { P available } \\
(\mathbf{m g} / \mathbf{1 0 0 g})\end{array}$ & $\begin{array}{c}\text { K total } \\
(\mathbf{\%})\end{array}$ \\
\hline Formula 1 & Control 1 & 0.91 & 38.7 & 0.18 & 33.3 & 0.18 \\
& Experiment 1 & 1.30 & 44.9 & 0.20 & 62.4 & 0.22 \\
Formula 2 & Control 2 & 1.17 & 41.2 & 0.19 & 15.6 & 0.23 \\
& Experiment 2 & 1.62 & 45.5 & 0.21 & 29.8 & 0.39
\end{tabular}

Solid wastes of arrowroot after cultivating the blueworms have contents of $\mathrm{N}, \mathrm{P}$ and $\mathrm{K}$ levels higher than control samples. This tendency was similar in the two experiment formulas, for example total nitrogen content increased from $0.91 \%$ to $1.30 \%$ in formula 1 and increased from $1.17 \%$ to $1.62 \%$ in the formula 2 . The content of nitrogen and phosphorus in available forms significantly increased, especially high in case of phosphorus. In Formula 1: available phosphorus increased from $33.3 \mathrm{mg} / 100 \mathrm{~g}$ to $62.4 \mathrm{mg} / 100 \mathrm{~g}$; and in formula 2: from $15.6 \mathrm{mg} / 100 \mathrm{~g}$ to $29.8 \mathrm{mg} / 100 \mathrm{~g}$.

Thus, the blueworms had an important contribution in the treatment of organic matter of arrowroot solid wastes in which the materials were decomposed from persistent forms into available forms. In addition, we also gained the blueworms, which are also a good source of protein food for livestock and poultry.

\section{Conclusion}

Duong Lieu village is an agricultural product processing area in Hanoi. This village disposed of about 400-500 tons of solid wastes per day. About $95 \%$ of the waste residues from arrowroot were not reused, and were the main cause of environmental pollution that needs to be researched and solved. Compositions of dried solid wastes of arrowroot were mainly carbon-rich substances and small amounts of $\mathrm{N}, \mathrm{P}$ and $\mathrm{K}$. These are the nutrients needed for living organisms; that means these substances are easily biodegradable. So, we can treat solid wastes of arrowroot by biological methods.
Finding a process to treat solid wastes of arrowroot on the laboratory scale, like reusing them as raw materials for mushroom cultivation, raising blueworms (Perionyx excavates) and producing vermicompost fertilizer as well. Gained productions of arrowroot waste treatment process are the kind of nutritious foods for human such as straw mushroom and oyster mushroom. Besides, vermicompost fertilizer for crop plants and the blueworm production are also economic benefits.

\section{Reference}

[1] Nguyen, H.D., Dinh, X.L., Nguyen, T.S., Zani, F. 1997. Mushroom - Basis of scientific and technological cultivation. Agricultural Publishing House.

[2] Nguyen, D.H. 1998. Environmental rapid assessment and Project.

[3] Le, V.K., Tran, K.H., Trinh, T.T. 1996. Agricultural Chemistry. Publisher Hanoi National University.

[4] Dang, K.C. 2005. Vietnamese trade village and Environment. Publisher of scientific and techniques.

[5] Committee of Hoai Duc district 2007. Report of trade village environment Hoai Duc

[6] Vietnam Environment Administration 2008. Report for National Environment - Vietnamese trade village Environment. http://vea.gov.vn

[7] Vietnamese trade village. www.langnghe.org.vn 